\title{
PELUANG DAN TANTANGAN PENGADILAN AGAMA POLEWALI MANDAR DALAM MENSOSIALISASIKAN PERKARA EKONOMI SYARIAH
}

\author{
Abd. Hamid \\ Prodi Hukum Ekonomi Syariah, Fakultas Agama Islam, Universitas Al Asyariah Mandar \\ abdulhamid@yahoo.co.id
}

\begin{abstract}
Abstrak
Geliat Perbankan Syari'ah kian terasa pesat dengan makin banyaknya perbankan syari'ah yang lahir dalam perbankan nasional. Tidak hanya Bank-Bank baru yang lahir dengan membawa konsep syari'ah, tetapi juga Bank-Bank Konvensional juga menghadirkan nuansa baru dengan melahirkan sistem syari'ah dalam perbankan konvensional tersebut. Seperti halnya BRI Syari'ah, BNI Syari'ah, Bank Syari'ah Mandiri dan sebagainya. Sebagaimana kita ketahui bahwa Bank-Bank tersebut dikenal dengan nama besarnya sebagai Bank Konvensional. Namun perkembangan perbankan syari'ah tidak diikuti secara linear oleh peraturan perundang-undangan yang mengaturnya terutama mengenai penyelesaian sengketa. Pengadilan Negeri tidak menggunakan syari'ah sebagai landasan hukum bagi penyelesaian perkara, sedangkan wewenang Pengadilan Agama telah dibatasi UU No. 3 Tahun 2006. Institusi ini hanya dapat memeriksa dan mengadili perkara-perkara yang menyangkut orang yang beragama islam, sedangkan pelaku yang terlibat di dalam proses perbankan syari'ah tidak hanya kalangan islam semata. Oleh karena itu perlu halnya dibentuk aturan hukum baru atau peradilan baru dalam menyelesaikan perkara syari'ah demi tercapainya cita-cita hukum dan tertib hukum terutama pada bidang perbankan syari'ahdiIndonesia.
\end{abstract}

Kata Kunci: Perbankan Syari'ah, Sengketa Syari'ah, Pengadilan.

\section{Pendahuluan}

Hukum Islam sebagai sebuah hukum yang hidup di Indonesia mengalami perkembangan yang cukup berarti dalam masa kemerdekaan. Perkembangan tersebut antara lain dapat dilihat dari kewenangan yangdimiliki oleh Peradilan Agama sebagai peradilan Islam di Indonesia. Dulunya, putusan Pengadilan Agama murni berdasarkan fiqh para fuqaha', eksekusinya harus dikuatkan oleh Peradilan Umum, para hakimnya hanya berpendidikan syari'ah tradisional dan tidak berpendidikan hukum, organisasinya tidak berpuncak ke Mahkamah Agung, dan Iain-lain. Sekarang keadaan sudah berubah. Salah satu perubahan mendasar akhir akhir ini adalah penambahan kewenangan Pengadilan Agama dalam Undang-Undang Peradilan agama yang baru, antara lain bidang ekonomi Syari'ah. Makalah ini membahas mulai dari Kewenangan Peradilan Agama, Pengertian Ekonomi Syari'ah dan Macam-macamnya, terjadinya Sengketa Ekonomi Syari'ah, Penyelesaian Sengketa Ekonomi Syari'ah. 
Pengadilan Agama Sebagai salah satu dari empat peradilan yang ada di Indonesia. semenjak diundangkannya Nomor 3 Tahun 2006 tentang perubahan atas Nomor 7 tahun 1989 tentang peradilan agama, mempunyai wewenang baru sebagai bagian dari yurisdiksi absolutnya, yaitu kewenangan untuk menerima, memeriksa dan mengadili serta menyelesaikan sengketa dibidang ekonomi syari'ah.

Wewenang baru tersebut bisa dikatakan sebagai tantangan dan sekaligus peluang bagi lembaga peradilan agama. Dikatakan sebagai tantangan karena selama ini bagi polewali mandar belum ada pengalaman dalam menyelesaikan sengketa di bidang ekonomi syari'ah, sehingga kalau pun sekiranya datang suatu perkara tentang sengketa ekonomi syariah maka bagi lembaga peradilan agama ini mesti mencari dan mempersiapkan diri dengan seperangkat peraturan perundangan maupun norma hukum yang terkait dengan persoalan ekonomi syariah. ${ }^{1}$

Secara rinci, dapat dikemukakan mengenai bentuk-bentuk sengketa bank syari'ah yang disebabkan karena adanya pengingkaran atau pelanggaran terhadap perikatan (akad) yang telah dibuat, yaitu disebabkan karena:

1. Kelalaian Bank untuk mengembalikan dana titipan nasabah dalam akad wadi'ah

2. Bank mengurangi nisbah keuntungan nasabah tanpa persetujuan yang bersangkutan dalam akad mudlorobah

3. Nasabah melakukan kegiatan usaha minuman keras dan usaha-usaha lain yang diharamkan menurut syari'at Islam yang bersumber dari dana pinjaman bank syari'ah, akad qirah dan lain-lain

4. Pengadilan agama berwenang menghukum kepada pihak nasabah atau pihak bank yang melakukan wanprestasi yang menyebabkan kerugian riil (real lose).

Berdasarkan latar belakan di atas ,maka permasalahan dalam penelitian ini adalah Bagaimana peran aktif pengadilan agama polewali mandar dalam mensosialisasikan perkara ekonomi ?Bagaimana prosedur penyelesaian sengketa ekonomi syariah di Pengadilan Agama ?

Adapun tujuan dari penelitian ini adalah untuk memperhatikan pokok masalah tersebut di atas, maka tujuan penelitian ini adalah: Memberikan kesadaran kepada Pengadilan Agama Polewali Mandar bahwasanya masih banyak masyarakat awan dan lembaga/instansi yang berujuk kepada hukum belum paham betul dengan apa yang menjadi kewenangan absolut.

Mengetahui sejauh mana pengadilan agama polewali mandar dalam mensosialisasikan perkara ekonomi ,karnah penulis mengetahui bahwa belum pernah pengadilan agama Polewali Mandar menangani sengketa ekonomi .sedangkan penulis mengetahui bahwasanya di daerah Polewali Mandar itu sudah banyak lembaga/instansi yang berbasis .

Kegunaan

Penelitian ini diharapkan mampu memberikan deskripsi yang jelas tentang kompetensi pengadilan agama polewali mandar dan berbagai kendala yang dihadapi serta upaya-upaya yang dilakukan oleh hakim-hakim Surakarta berkaitan dengan kesiapan menyelesaikan masalah ekonomi syari'ah. Sehingga penelitian ini diharapkan mampu menjadi bahan evaluasi serta bahan acuan bagi peradilan Agama.

Memberikan kontribusi positif bagi perkembangan studi Islam.

${ }^{1}$ Jaenal Aripin, Peradilan Agama dalam Bingkai Reformasi Hukum di Indonesia (Jakarta: Kencana, 2008)h 343. 


\section{TINJAUAN PUSTAKA \\ A. Pengadilan Agama}

Pengertian Pengadilan Agama Pengadilan menurut bahasa adalah dewan atau majelis yang mengadili perkara, mahkamah, proses mengadili keputusan hakim ketika mengadili perkara (bangunan tempat mengadili perkara).Sedangkan pengadilan agama merupakan terjemahan dari (Godsdienstige Rechtspraak) yang berarti Pengadilan Agama. Pengadilan Agama adalah daya upaya untuk mencari keadilan atau penyelesaian perselisisihan hukum yang dilakukan menurut peraturan - peraturan dalam agama. $^{2}$

Pengadilan agama adalah sebutan (titelateur) resmi bagi salah satu diantara empat lingkungan peradilan negara atau kekuasaan kehakiman yang sah di Indonesia. Pengadilan Agama juga salah satu diantara tiga peradilan khusus di Indonesia . dua peradilan khusus lainnya adalah Peradilan Militer dan Peradilan Tata Usaha Negara. Dikatakan peradilan khusus karena Pengadilan Agama mengadili perkara - perkara tertentu atau mengenai golongan rakyat tertentu (yang beragama Islam).

Dalam hal ini, Peradilan Agama hanya berwenang dibidang perdata tertentu saja, tidak dalam bidang pidana dan juga hanya untuk orang - orang

Pengadilan Agama tidak berwenang untuk menyita barang dan uang tidak adanya kewenangan yang seperti ini terus berlangsung sampai dengan lahirnya Undangundang Nomor 1 Tahun 1974 tentang Perkawinan. Sehingga lahirnya firman Raja Belanda (Koninklijk Besluit) tanggal 19 Januari 1882 Nomor 24, Staatsblad 1882 - 152 telah mengubah susunan dan status peradilan agama kedalam Wewenang pengadilan agama yang disebut dengan preisterraacf tetap daIam bidang perkawinan dan kewarisan, serta pengakuan dan pengukuhan akan keberadaan pengadilan agama yang telah ada sebelumnya, dan hukum Islam sebagai pegangannya.

Berlakunya Staatsblad 1937 Nomor 116 telah mengurangi kompentensi Pengadilan Agama di Jawa dan Madura daIam bidang perselisihan harta benda, yang berarti masalah wakaf dan waris harus diserahkan kepada pengadilan negeri. Mereka atau Pemerintah Kolonial Belanda yang berdalih, bahwa dalam kenyataan kehidupan bermasyarakat, hukum Islam tidak mendalam pengaruhnya pada aturan-aturan kewarisan dalam keluarga Jawa dan Madura serta di tempat-tempat lain di seluruh Indonesia.

Sehingga pada tanggal 3 Januari 1946 dengan Keputusan Pemerintah Nomor 1 JSD dibentuk Kementrian Agama, kemudian dengan Penetapan Pemerintah tanggal 25 Maret 1946 Nomor 5/ semua urusan mengenai Mahkamah Islam Tinggi dipindahkan dari Kementrian Kehakiman ke dalam Kementrian Agama.

Langkah ini memungkinkan konsolidasi bagi seluruh administrasi lembagalembaga Islam dalam sebuah wadah yang besifat nasional. Berlakunya Undang-undang Nomor 22 Tahun 1946 menunjukkan dengan jelas maksud- maksud untuk

mempersatukan administrasi Nikah, Talak dan Rujuk di seluruh wilayah Indonesia di bawah pengawasan Kementrian Agama. Usaha untuk menghapuskan

2 M Yahya Harahap, hlm.,137 Kedudukan Kewenangan dan Acara Peradilan Agama (No. 7 Tahun 1989) Pustaka Kartini, Jakarta, 1997, hal.15. 
pengadilan agama masih terus berlangsung sampai dengan keluarnya Undang-undang Nomor 19 Tahun 1948 dan Undang-undang Darurat Nomor 1 Tahun 1951 tentang Tindakan Sementara untuk Menyelenggarakan Kesatuan Susunan, Kekuasaan dan Acara Pengadilan-pengadilan Sipil, antara lain mengandung ketentuan pokok bahwa peradilan agama merupakan bagian tersendiri dari peradilan swapraja dan peradilan adat tidak turut terhapus dan kelanjutannya diatur dengan peraturan pemerintah. Proses keluarnya peraturan pemerintah inilah yang mengalami banyak hambatan, sehingga dapat keluar setelah berjalan tujuh tahun dengan keluarnya Peraturan Pemerintah Nomor 45 Tahun 1957.

Dengan keluarnya Undang-undang Nomor 14 Tahun 1970 tentang Ketentuanketentuan Pokok Kekuasaan Kehakiman, maka kedudukan Peradilan Agama mulai nampak jelas dalam sistem peradilan di Indonesia. Undang-undang ini menegaskan prinsip-prinsip sebagai berikut:

Peradilan dilakukan demi Keadilan Berdasarkan ketuhanan Yang Maha Esa, Kekuasaan kehakiman dilakukan oleh pengadilan dalam lingkungan Peradilan Umum, Peradilan Agama, Peradilan Militer dan Peradilan Tata Usaha Negara, Mahkamah Agung adalah Pengadilan Negara Tertinggi. Badan-badan yang melaksanakan peradilan secara organisatoris, administratif, dan finansial ada di bawah masing-masing departemen yang bersangkutan. susunan kekuasaan serta acara dari badan peradilan itu masing-masing diatur dalam undang-undang tersendiri.

Hal ini dengan sendirinya memberikan landasan yang kokoh bagi kemandirian Peradilan Agama, dan memberikan status yang sama dengan peradilan-peradilan lainnya di Indonesia. Lahirnya Undang-undang Nomor 1 Tahun 1974 tentang Perkawinan memperkokoh keberadaan pengadilan agama.Di dalam undang $\neg$ undang ini tidak ada ketentuan yang bertentangan dengan ajaran Islam pasal 2 ayat (1) undangundang ini semakin memperteguh pelaksanaan ajaran Islam atau hukum Islam.

Suasana cerah kembali mewarnai perkembangan peradilan agama di Indonesia dengan keluarnya Undang-undang Nomor 7 Tahun 1989 tentang Peradilan Agama yang telah memberikan landasan untuk mewujudkan peradilan agama yang mandiri, sederajat dan memantapkan serta mensejajarkan kedudukan peradilan agama dengan lingkungan peradilan lainnya.

Dasar Hukum Pengadilan Agama

a. Al-quran

b. As-sunnah

\section{B. Pengertian pengadilan agama}

Dalam kamus Bahasa Indonesia, peradilan adalah segala sesuatu mengenai perkara peradilan.Peradilan juga dapat diartikan suatu proses pemberian keadilan disuatu lembaga. Dalam kamus Bahasa Arab disebut dengan istilah qadha yang berarti menetapkan, memutuskan, menyelesaikan, mendamaikan.

Qadha menurut istilah adalah penyelesaian sengketa antara dua orang yang bersengketa, yang mana penyelesaiannya diselesaikan menurut ketetapan-ketetapan (hukum) dari Allah dan Rasul. Sedangkan pengadilan adalah badan atau organisasi yang diadakan oleh negara untuk mengurus atau mengadili perselisihan-perselisihan hukum.

Peradilan Agama adalah proses pemberian keadilan berdasarkan hukum agama Islam kepada orang-orang Islam yang dilakukan di Pengadilan agama dan Pengadilan Tinggi Agama. Sebagai lembaga peradilan, peradilan agama dalam 
bentuknya yang sederhana berupa tahkim, yaitu lembaga penyelesaian sengketa antara orang-orang Islam yang dilakukan oleh para ahli agama, dan telah lama ada dalam masyarakat indonesia yakni sejak agama islam datang ke Indonesia. ${ }^{3}$

\section{Ruang Lingkup Pengadilan Agama}

1. Berdasarkan Pasal 2. Pasal 49 Undang-Undang Nomor 3 Tahun 2006 tentang Perubahan atas Undang-undang Nomor 7 Tahun 1989 Tentang Peradilan Agama, Tugas pokok Pengadilan Agama adalah memeriksa, memutus, dan menyelesaikan perkara tertentu antara orang-orang yang beragama Islam di bidang:
a) perkawinan,
b) waris,
c) wasiat,
d) hibah,
e) wakaf,
f) zakat,
g) Infaq,
h) shadaqah; dan
i) ekonomi syari'ah.

2. Sedangkan Fungsi Pengadilan Agama antara lain sebagai berikut

a) Fungsi mengadili yakni menerima, memeriksa, mengadili dan menyelesaikan perkara-perkara yang menjadi kewenangan Pengadilan Agama dalam tingkat pertama (Pasal 49 Undang-undang Nomor 3 Tahun 2006).

b) Fungsi pembinaan, yakni memberikan pengarahan, bimbingan, dan petunjuk kepada pejabat struktural dan fungsional di bawah jajarannya, baik menyangkut teknis yudicial, administrasi peradilan, maupun administrasi umum/perlengkapan, keuangan, kepegawaian, dan pembangunan. ( Pasal 53 ayat (3) Undang-undang Nomor No. 3 Tahun 2006 . KMA Nomor KMA/080/VIII/2006).

c) Fungsi pengawasan, yakni mengadakan pengawasan melekat atas pelaksanaan tugas dan tingkah laku Hakim, Panitera, Sekretaris, Panitera Pengganti, dan Jurusita/ Jurusita Pengganti di bawah jajarannya agar peradilan diselenggarakan dengan seksama dan sewajarnya ( Pasal 53 ayat (1) dan (2) Undang-undang Nomor No. 3 Tahun 2006) dan terhadap pelaksanaan administrasi umum kesekretariatan serta pembangunan. ( KMA Nomor KMA/080/VIII/2006).

d) Fungsi nasehat, yakni memberikan pertimbangan dan nasehat tentang hukum Islam kepada instansi pemerintah di daerah hukumnya, apabila diminta. ( Pasal 52 ayat (1) Undang-undang Nomor No. 3 Tahun 2006).

e) Fungsi administratif, yakni menyelenggarakan administrasi peradilan (teknis dan persidangan), dan administrasi umum (kepegawaian, keuangan, dan umum/perlengakapan) ( KMA Nomor KMA/080/ VIII/2006)

${ }^{3}$ Abdul Ghofur Anshori, peradilan Agama di indonesia pasca No. 3 Tahun2006 (Sejarah, Kedudukan dan Kewenangan), hal. 5. 
3. Tugas Ketua Pengadilan Agama

a) Memimpin pelaksanaan tugas Pengadilan Agama.

b) Menetapkan sasaran setiap tahun kegiatan.

c) Menetapkan dan menjadwalkan rencana kegiatan.

d) Membagi tugas dan menentukan penanggung jawab kegiatan.

e) Menggerakkan dan mengarahkan pelaksanaan kegiatan dilingkungan Pengadilan Agama.

f) Memantau pelaksanaan tugas bawahan.

g) Mengadakan rapat dinas.

h) Meningkatan koordinasi dengan instansi terkait.

i) Menanggapi dan memecahkan masalah yang muncul di lingkungan Pengadilan Agama.

j) Mengadakan konsultasi dengan atasan setiap saat diperlukan.

k) Menunjuk dan menetapkan majelis hakim serta mengatur pembagian perkara kepada para hakim dan melakukan sidang perkara

1) Menetapkan dan memerintahkan eksekusi/sita eksekusi dalam suatu putusan.

m) Memberikan nasihat tentang hokum islm kepada instansi pemerintah dan masyarakat sebagai upaya penyuluhan hukum.

n) Melaksanakan tugas khusus yang diberikan oleh atasan.

o) Mengevaluasi prestasi kerja aparat di lingkungan Pengadilan Agama.

p) Mengevaluasi prestasi kerja aparat di lingkungan Pengadilan Agama.

q) Melaporkan pelaksanaan tugas kepada Pengadilan Tinggi Agama.

4 .Tugas Wakil Ketua Pengadilan Agama Polewali

a) Memimpin pelaksanaan tugas Pengadilan Agama Polewali.

b) Menetapkan sasaran pelaksanaan tugas Pengadilan Agama Polewali.

c) Menetapkan dan menjadwalkan rencana kegiatan.

d) Membagi tugas dan menentukan penanggungjawab kegiatan.

e) Menggerakkan dan mengarahkan pelaksanaan kegiatan di lingkungan Pengadilan Agama.

f) Memantau pelaksanaan tugas para bawahan.

g) Mengadakan rapat dinas.

h) Menetapkan rumusan kebijaksanaan Pengadilan Agama.

i) Meningkatkan koordinasi dengan instansi terkait.

j) Menanggapi dan memecahkan masalh yang timbul di lingkungan Pengadilan Agama.

k) Mengadakan konsultasi dengan atasan setiap waktu diperlukan.

1) Menunjuk dan menetapkan majelis hakim serta mengatur pembagian perkara kepada para hakim untuk melakukan sidang perkara.

m) Menetapkan dan mememrintahkan eksekusi / sita eksekusi dalam putusan.

n) Menyebutkan kesaksian rukyah hilal awal bulan hijriah.

o) Memberikan nasihat tentang hukum islam kepada instansi pemerintah setempat sebagai upaya penyuluhan hukum.

p) Melaksanakan tugas khusus yang di berikan ketua.

q) Mengevaluasi prestasi kerja aparat di lingkungan Pengadilan Agama.

r) Melaporkan pelaksanaan tugas kepada Pengadilan Tinggi Agama. 
s) Mengkoordinir pelaksanaan tugas Hakim Pengawas Bidang.

4. Hakim Pengawas Bidang Gugatan / Permohonan

a) Mengawasi prosedur penerimaan perkara berdasarkan pada sistem meja I, kasir dan meja II.

b) Mengawasi pelaksanaan pembayaran panjar biaya perkara harus sesuai dengan radius dilakukan oleh kasir.

c) Mengawasi pelaksanaan pembayaran biaya dan penandatanganan SKUM harus dilakukan oleh kasir.

d) Mengawasi pemberian nomor perkara, baik dalam SKUM maupun dalam berkas harus dilakukan oleh kasir.

e) Mengawasi pengeluaran salinan putusan dan akta cerai harus dilakukan oleh meja III.

f) Mengawasi agenda pendaftaran dan paraf meja II pada surat gugatan/surat permohonan.

g) Mengawasi kelayakan alur jenis gugatan/permohonan yang diajukan Pengadilan Agama apakah sesuai dengan jenis perkara yang ada.

h) Mengawasi kelayakan gugatan/permohonan yang diajukan Pengadilan Agama sesuai kompetensinya atau bukan.

i) Mengawasi tanggal penetapan hari sidang apakah layak atau tidak dengan melihat kondisi daerah dengan jenis perkara yang ada.

j) Mengawasi penandatanganan surat gugatan/permohonan oleh penggugat/pemohon.

k) Mengawasi kemungkinan adanya gugatan lisan karena pihak penggugat/pemohon dalam keadaan tidak bisa membaca dan menulis.

1) Mengawasi materi gugatan/permohonan yang di dalamnya tercakup identitas para pihak, posita dan petitumnya.

m) Mengawasi pengajuan gugatan/permohonan oleh pihak penggugat/pemohon apakah benar yang bersangkutan dalam keadaan miskin (tidak mampu). ${ }^{4}$

\section{Perbedaan Pengadilan Agama Dengan Pengadilan Umum}

Pengadilan adalah badan atau instansi resmi yang melaksanakan sistem peradilan berupa memeriksa, mengadili, dan memutus perkara. Bentuk dari sistem Peradilan yang dilaksanakan di Pengadilan adalah sebuah forum publik yang resmi dan dilakukan berdasarkan hukum acara yang berlaku di Indonesia.

Sedangkan peradilan adalah segala sesuatu atau sebuah proses yang dijalankan di Pengadilan yang berhubungan dengan tugas memeriksa, memutus dan mengadili perkara dengan menerapkan hukum dan/atau menemukan hukum "in concreto" (hakim menerapkan peraturan hukum kepada hal-hal yang nyata yang dihadapkan kepadanya untuk diadili dan diputus) untuk mempertahankan dan menjamin ditaatinya hukum materiil, dengan menggunakan cara prosedural yang ditetapkan oleh hukum formal.

4 Muhammad Daud, "Hukum Islam dan Peradilan Agama”, Jakarta: Rajawali Press, 1997. 
Dari kedua uraian diatas dapat dikatakan bahwa, pengadilan adalah lembaga tempat subjek hukum mencari keadilan, sedangkan peradilan adalah sebuah proses dalam rangka menegakkan hukum dan keadilan atau suatu proses mencari keadilan itu sendiri."

Sebagai informasi untuk Anda, di Indonesia, badan peradilan yang berada di bawah Mahkamah Agung meliputi badan peradilan dalam lingkungan (Pasal 25 UU Kekuasaan Kehakiman):

peradilan umum berwenang memeriksa, mengadili, dan memutus perkara pidana dan perdata sesuai dengan ketentuan peraturan perundang-undangan

peradilan agama berwenang memeriksa, mengadili, memutus, dan menyelesaikan perkara antara orang-orang yang beragama Islam sesuai dengan ketentuan peraturan perundang-undangan. ${ }^{5}$

\section{E. Sosialisasi}

Secara garis besar pengertian sosialisasi dapat dipandang sebagai suatu proses belajar mengajar. Melalui sosialisasi, individu belajar menjadi anggota masyarakat, dimana prosesnya tidak semata mata mengajarkan pola pola perilaku sosial kepada individu tetapi juga individu tersebut mengembangkan dirinya atau melakukan proses pendewasaan dirinya. ${ }^{6}$

Sosialisasi bukan sekedar pemberitahuan kepada masyarakat luas atau lembagalembagaa/instansi akan tetapi sosialisasi juga bertujuan sebagai berikut;

1. Sosialisasi bertujuan agar tiap individu mendapatkan bekal keterampilan yang kelak nantinya akan dia butuhkan untuk tetap hidup.

2. Sosialiasi bertujuan agar setiap individu dapat berkomunikasi yang tentu saja dengan efektif sehingga kemampuan membaca, menulis, dan berbicara dapat berkembang.

3. Sosialisasi bertujuan agar mengendalikan fungsi fungsi organik melalui latihan latihan mawas diri yang tepat

4. Sosialisasi bertujuan sehingga setiap individu dapat membiasakan dirinya dengan nilai nilai dan kepercayaan pokok yang ada pada masyarakat.

5. Membentuk sistem perilaku melalui pengalaman yang dipengaruhi oleh watak pribadinya, yaitu bagaimana ia memberikan reaksi terhadap suatu pengalaman menuju proses pendewasaan

\section{F. Perkara Ekonomi Syariah}

1. Pengertian Perkara Ekonomi

perkara ekonomi adalah perkara yang menjadi kompetensi absolud bagi pengadilan agama,dan mungkinterlebih dahulu penulis memperluas pengertian tentang ekonomi dari berbagai pakar ekonomi diantaranya adalah;

a) Pengertian Ekonomi atau Pengertian Ekonomi Islam menurut M.A. Manan adalah ilmu pengetahuan sosial yang mempelajari masalah-masalah ekonomi rakyat yang diilhami oleh nilai-nilai Islam.

5Anshari, Abdul Ghofur, Peradilan Agama Di Indonesia Pasca UU No. 3 Tahun 2006 (sejarah, kedudukan dan kewenangan)

${ }^{6}$ Mohammad daud Ali, Hukum Islam (Jakarta: PT. Rajagrafindo Persada, 2012) hal 283 
b) Menurut Muhammad Abdullah al-'Arabi, Pengertian Ekonomi syariah atau Pengertian Ekonomi Islam ialah sekumpulan dasar-dasar umum ekonomi yang kita simpulkan dari Al-quran dan Sunnah, dimana merupakan bangunan perekonomian yang didirikan di atas landasan dasar-dasar tersebut sesuai tiap lingkungan dan masa.

c) Menurut Prof. Dr. Zainuddin Ali, Pengertian Ekonomi atau Pengertian Ekonomi Islam adalah kumpulan norma hukum yang bersumber dari alquran dan hadist yang mengatur perekonomian umat manusia.

d) Menurut Dr. Mardani, Pengertian Ekonomi atau Pengertian Ekonomi Islam yaitu usaha atau kegiatan yang dilakukan oleh orang per orang atau kelompok orang atau badan usaha yang berbadan hukum atau tidak berbadan hukum dalam rangka memenuhi kebutuhan yang bersifat komersial dan tidak komersial menurut prinsip .

\section{METODE PENELITIAN}

Dalam melakukan penelitian ini, penulis mengambil lokasi sesuai dengan judul skripsi "peluang dan tantangan pengadilan agama polewali mandar dalam mensosialisasikan perkara ekonomi syariah". (Studi Kasus di Pengadilan Agama polewali mandar Tahun 20162017). Sehingga berdasarkan skripsi ini, maka lokasi penelitian ialah Pengadilan Agama polewali mandar.

Jenis Penelitian ini merupakan penggabungan dari penelitian normative, penelitian empiris. Dan penelitian lapangan. Penelitian normative dilakukan dengan cara mempelajari data sekunder berupa buku-buku dan per Undang-undangan yang berkaitan dengan masalah yang dibahas, penelitian empiris dilakukan dengan menganalisa penetapan Pengadilan Agama polewali mandar dari beberapa penetapan dan penelitian lapangan (field research adalah penelitian yang sumber datanya terutama diambil dari objek penelitian (masyarakat atau komunitas sosial) secara langsung didaerah penelitian.

Metode Pendekatan ini dilakukan dan ditunjukan pada praktek pelaksanaan hukum (law in action ) terhadap peraturan perundang-undangan yang tertulis serta prateknya dan dokumen-dokumen hukum yang ada di Indonesia (law in books ), maka metode pendekatannya bersifat Kualitatif Yuridis Normatif.Normative Theory Pada dasarnya normative theory merupakan teori yang sudah lama ada dalam lingkupdisiplin Hubungan Internasional. Namun demikian, studi-studi yang bersifat normative dalam prakteknya tidak mendapat tempat inti dalam konstelasi hubungan internasional yang diakibatkan

Sosiologis NormatifMasyarakat Indonesia pada dewasa ini sedang berada dalam arus perubahan yang terjadi secara cepat dan cukup mendasar. Terjadinya perubahan dari masyarakat yang semula bebasis agraris menuju masyarakat industri, tentunya akan selalu diikuti oleh penyesuain pada segi kehidupan hukumnya, baik itu berupa hukum positipnya maupun penyesuaian di bidang peradigmatif, landasan filosofis, teori dan konsepsi serta pengertian-pengertian.

Dalam abad 20 ini susunan masyarakat menjadi semakin kompleks, spesialisasi dan pemencaran bidang-bidang dalam masyarakat semakin intensif berkembang dan maju. Dengan demikian pengaturan yang dilakukan oleh hukum juga harus mengikuti perkembangan keadaan yang demikian 
Populasii adalah seluruh sumber data yang bisa di jangkau populasi dalam penelitian ini adalah seluruh yang mengajukan perkara sengketa ekonomi syariah di pengadilan agama polewali mandar

Sampel adalah sebagian sumber data yang di ambil dari populasi. Idealnya prosedur penarikan sampel itu harus dilakukan sedemikian rupa sehingga setiap unit didalam populasi memperoleh kesempatan yang sama.Sampel merupakan bagian populasi yang diangap mewakili dari semua objek dari sasaran penelitian atau prosese menarik sebagian subjek ${ }^{7}$ Disamping itu, sutrisno hadi mengatakan bahwa sampel adalah "sebagian induvidu yang di teliti”"Sampel di pergunakan untuk penelitian yang sifat dan karakternya dapat mewakili populasi sebagai subjek penelitian. Untuk memelih populasi maka peneliti memilih sampel dari populasi terseut. Dalam penentuan sampel, penulis memgambil

Metode Pengumpulan DataGuna memperoleh data yang akurat, tepat dan jelas penyusun ini menggunakan:

Observasi (pengamatan langsung), yaitu mengamati langsung kelapangan dalam hubungannya dengan masalah yang akan diteliti untuk dianalisa dan dikumpulkan.

Interview (wawancara) adalah cara pengumpulan data yang dilakukan dengan bertanya jawaban langsung dari sumber utama data. Dari hal ini penyusun menggunakan wawancara terpimpin, ini akan memberi kemudahan baik dalam mengemukakan pertanyaan maupun dalam menganalisa untuk mengambil keputusan atau kesimpulan. Disamping itu penyusun juga menggunakan wawancara bebas, karena hal ini akan memudahkan diperolehnya data secara mendalam. Wawancara dilakukan pada informasi

Dalam penelitian kualitatif yuridis normatif, analisa data yang digunakan adalah secara induktif. Proses data dimulai dengan penyeleksian data yang telah dikumpulkan, kemudian dikelasifikasikan

Konsep Dasar Analisi Data.Menurut Patton, 1980 (dalam Lexy J. Moleong 2002: 103) menjelaskan bahwa analisis data adalah proses mengatur urutan data, mengorganisasikanya ke dalam suatu pola, kategori, dan satuan uraian dasar. Sedangkan menurut Taylor, (1975: 79) mendefinisikan analisis data sebagai proses yang merinci usaha secara formal untuk menemukan tema dan merumuskan hipotesis (ide) seperti yang disarankan dan sebagai usaha untuk memberikan bantuan dan tema pada hipotes.

\section{HASIL PENELITIAN}

\section{A. Bagaimana Peran Aktif Pengadilan Agama Polewali Mandar Dalam Mensosialisasikan Perkara Ekonomi Syariah}

Peran Pengadilan Agama Polewali Mandar dalam mensosialisasikan perkara ekonomi syariah itu dapat di ketahui melalui wawancara yang selama ini di laksanakan oleh peneliti.Sumber data yang di jadikan referensi oleh peniliti berasal dari wawancara yang di lakukan kepada pihak yang terkait di dalamnya.

Berikut ini penjelasan dari beberapa nara sumber yang telah di wawancarai selama masa penelitian dan peneliti merangkum semua penjelasan mengenai perkara ekonomi syariah.

"Pengadilan Agama Polewali Mandar yang bernama ibu Ferawati yang diposisikan di meja satu(1) sebagai staf beliau menerangkan bahwa selama beliau bertugas di Pengadilan Agama Polewali Mandar beliau tidak pernah menerima

7Ibid, h.51-52

${ }^{8}$ Sutrisno Hadi, loc.cit 
perkara ekonomi syariah Adapun perkara yang sering masuk di Pengadilan Agama Polewali Mandar adalah perkara sengketa dan pernikahan baik permohonan maupun gugatan. ${ }^{9}$

Hal ini dapat membuktikan bahwa sengketa ekonomi syariah tidak pernah di limpahkan ke pengadilan agama polewali mandar di mana pada dasarnya sengketa ekonomi syariah itu sudah menjadi kewenang pengadilan agama semenjak perunbahan Undang-Undang no 7 tahun 1989 menjadi Undang- Undang no 3 tahun 2016 perkara ekonomi syariah itu sudah menjadi kewenangan absolutnya pengadilan agama

"Ibu Misna Surya selaku kepala urusan kepegawaian menerangkan bahwa selama beliau bertugas di pengadilan agama polewali mandar beliau tidak pernah menerimah surat perintah dari Mahkamah Agung untuk turun ke masyarakat secara rombongan dalam rangka mensosialisasikan perkara ekonomi syariah. ${ }^{10}$

Selanjnutnya tentang kesiapan SDM Pengadilan Agama dalam menangani sengketa ekonomi syariah termasuk perbankan syariah,

1. Bahwa secara umum peradilan agama sudah siap menerima, memeriksa, dan memutus perkara sengketa ekonomi syariah yang diajukan oleh para pihak yang bersengketa sesuai dengan perintah Pasal 49 Undang-Undang Nomor 3 Tahun 2006 tentang Peradilan Agama .

2. Bahwa secara umum sumber daya manusia (SDM) para hakim di Pengadilan agama sudah siap untuk menerima, memeriksa, memutus dan menyelesaikan mempunyai pengetahuan tentang ekonomi syariah dan sejak diberikannya kewenangan sengketa ekonomi syariah ini kepada Pengadilan Agama, para hakim telah diberikan pelatihan-pelatihan dan pengetahuan mengenai ekonomi syariah.

3. Bahwa secara umum kesiapan sarana dan prasarana untuk menerima, memeriksa, dan memutus perkara sengketa ekonomi syariah di PengadilanAgama sudah memadai, namun di beberapa pengadilan agama masih perlu penyiapan gedung yang memadai.

"Dr.Muhammad Najmi S.HI M.H. menerangkan bahwa selama beliau bertugas di Pengadilan Agama sebagai hakim, beliau tidak pernah menyelesaikan perkara ekonomi syariah bahkan beliau menuturkan bahwa seandainya ada pernah masuk perkara ekonomi syariah di Pengadilan Agama Polewali Mandar maka harus yang berhak mengadili itu adalah hakim yang sudah sertifikasi dan sudah pernah mengikuti pelatihan-pelatihan mengenai sengketa syariah.

B. Prosedur Penyelesaian Sengketa Perbankan Syariah Di Pengadilan Agama

Apabila upaya penyelesaian melalui perdamaian tidak berhasil, di mana kedua belah pihak ternyata tidak menemui kata sepakat untuk menyelesaikan perkaranya secara damai maka sesuai dengan ketentuan Pasal 115 R.Bg atau Pasal 131 HIR ayat (1) dan (2) Pasal 18 ayat (2) PERMA hakim harus melanjutkan pemeriksaan perkara tersebut sesuai dengan ketentuan hukum acara yang berlaku. Dengan demikian, perkara tersebut akan diperiksa dan diselesaikan melalui proses persidangan sebagaimana mestinya. 2017.

${ }^{9}$ Ferawati selaku bagian dari lembaga pengadilan agama polewali mandar 20 maret

10 Misna Surya wawancara oleh penulis 22 maret 2017 
Penyelesaian perkara perbankan syariah di lingkungan peradilan agama akan dilakukan sesuai dengan ketentuan hukum acara perdata sebagaimana yang berlaku di lingkungan peradilan umum. Artinya, setelah upaya damai ternyata tidak berhasil maka hakim melanjutkan proses pemeriksaan perkara tersebut di persidangan sesuai dengan ketentuan hukum acara perdata yang dimaksud.

Dalam mengadili perkara, hakim mencari hukumnya dari sumber-sumber yang sah dan menafsirkannya, untuk kemudian diterapkan pada fakta atau peristiwa konkrit yang ditemukan dalam perkara tersebut Sumber-sumber hukum yang sah dan diakui secara umum, khususnya di bidang bisnis adalah isi perjanjian, undang-undang,yurisprudensi, kebiasaan, perjanjian internasional, dan ilmu pengetahuan

Adapun bagi lingkungan peradilan agama, sumber-sumber hukum yang terpenting untuk dijadikan dasar dalam mengadili perkara-perkara perbankan syariah setelah Al-Quran dan AS-Sunnah sebagai sumber utama.

Fatwa-fatwa DSN yang dapat dijadikan sumber hukum dalam mengadili perkara perbankan syariah adalah meliputi seluruh fatwa DSN di bidang perbankan syariah. Seperti diketahui fatwa tidak lain adalah merupakan produk pemikiran hukum islam yang bersifat kasuistik yang umumnya merupakan respons atas pertanyaan yang diajukan peminta fatwa. Pada dasarnya fatwa memang tidak memiliki daya ikat, baik terhadap peminta fatwa sendiri lebih lebih terhadap pihak lain. Namun dalam mengadili perkara perbankan syariah di pengadilan agama, khususnya fatwa DSN di bidang perbankan syariah, tampaknya mempunyai kedudukan dan perlu diperlakukan tersendiri. ${ }^{11}$

\section{PENUTUP}

\section{A. Kesimpulan}

Penelitian kualitatif adalah suatu penelitian yang ditujukan untuk mendeskripsikan dan menganalisis fenomena, peristiwa, aktivitas sosial, sikap, kepercayaan, persepsi, pemikiran, orang secara individual maupun kelompok, berguna untuk menemukan prinsipprinsip dan penjelasan yang mengarah pada penyimpulan. Penelitian kualitatif bersifat induktif, peneliti membiarkan permasalahan-permasalahan muncul dari data atau dibiarkan terbuka untuk interpretasi.

Data dihimpun dengan pengamatan yang seksama, mencakup deskripsi dalam konteks yang mendetail disertai catatan-catatan hasil wawancara yang mendalam, serta hasil analisis dokumen dan catatan-catatan. Penelitian kualitatif tidak berangkat dari dan untuk menguji teori, tetapi membangun teori, meskipun demikian mustahil peneliti kualitatif tidak memerlukan teori. Dalam konteks ini, fungsi teori dalam suatu kerja penelitian kualitatif digunakan untuk "menjelaskan atau mengklarifikasi" kecenderungan fenomena-fenomena, peristiwa, aktivitas sosial, sikap, kepercayaan, persepsi, pemikiran, subjek yang diteliti. Kebanyakan penelitian kualitatif bersifat deskriptif dan eksplanatori. Beberapa penelitian memberikan deskripsi tentang situasi yang kompleks, dan arah bagi penelitian selanjutnya.

1. Peluang dan tantangan pengadilan agama polewali mandar itu tidak di mamfaatkan dengan baik dimana pengadilan agama polewali mandar hanya mensosialisasikan perkara perkara yang menjadi konpotensi absolud di dalam web pengadilan agama polewali mandar tidak di lakukan secara lansung.

${ }^{11}$ Abdul Manan, Penerapan Hukum Acara Perdata di Lingkungan Peradilan Agama (Jakarta: Prenada Media. 2005). 
2. Berdasarkan hasil wawancara dari pihak perbankkan syariah penulis menyimpulkan bahwasanya sengketa ekonomi syariah itu memang pernah ada dan terjadi di bank tersebut hanya saja mereka menyelesaikan secara kekeluargaan dan ketika mereka tidak mampu menyelesaikan maka di alihkan ke pengadilan negri bukan pengadilan agama padahal sengketa syariah semenjak berubahnya UU no 7 tahun 1989 menjadi UU no 3 tahun 2016 itu segala perkara yg berkaitan dengan ekonomi syariah itu menjadi konpotensi absolud pengadilan agama.

\section{B. Saran}

untuk menemukan sebuah jawaban dari apa yang menjadi pertanyaan selama ini bahwa pengadilan agama polewali mandar tidak pernah menerimah perkara sengketa ekonomi syariah perlu kita cermati bahwa perkara ekonomi syariah sangat minim terjadi di daerah polewali mandar mengapa demikian di karenakan persoalan tidak berjalannya sebuah sistem yang berupa sosialisasi kepada masyarakat dan pihak perbankkan syariah. Ketika sosialisasi ini terjadi maka penulis yakin penerapan perkara ekonomi syariah berjalan dengan baik sebab sudah banyak hakim-hakim yang mampu menerapkan hukum syariah.

\section{Daftar Pustaka}

Aripin Jaenal, Peradilan Agama dalam Bingkai Reformasi Hukum di IndonesiaJakarta: Kencana, 2008 Roihan A Rosyd, Hukum Acara Peradilan Agama Jakarta: RajaGrafindo Persada.2003), 25-27

Mujahidin ahmad, Prosedur Penyelesaian Sengketa Ekonomi Syari'ah di Indonesia Bogor: Ghalia Indonesia, 2010.

Undang-Undang No. 4 Tahun 2004 tentang Pokok Kekuasaan Kehakiman.

Dalam bukunya Harahap M. Yahya, Kedudukan Kewenangan dan Acara Peradilan Agama Undang-UndangNo. 7 Tahun 1989 Pustaka Kartini, Jakarta, 1997

Tri Whyudi Abdullah, Peradilan Agama di Indonesia Yogyakarta: Pustaka Pelajar, 200487

Arikunto Suharsimi, Prosedur Penelitian Suatu Pendekatan, Rineka Cipta, Jakarta, 1993

Harahap M Yahya, hlm.,137 Kedudukan Kewenangan dan Acara Peradilan Agama No. 7 Tahun 1989 Pustaka Kartini, Jakarta, 1997

Anshori Abdul Ghofur, peradilan Agama di indonesia pasca No. 3 Tahun2006 (Sejarah, Kedudukan dan Kewenangan.

Tri Whyudi Abdullah, Peradilan Agama di Indonesia Yogyakarta: Pustaka Pelajar, 2004

Burhanuddin, Hukum Bisnis Syari'ah Yogyakarta: UII Press, 2011.

Al quran kementrian agama dalam bentuk aplikasi surah Surat An-Nisa`ayat: 58, 65 dan 105 .Al-Maidah ayat: 45. Surat Saad ayat: 26

Moh. Taufik Makarao, Pokok-pokok Hukum Acara Perdata, Rineka Cipta, Jakarta, 2004, http://amirsyampa.blogspot.com/2012/01/makalah-peran-peradilan-agama-dalam.html,

Abdul Ghofur Anshori, peradilan Agama di indonesia pasca No. 3 Tahun2006 Sejarah, Kedudukan dan Kewenanga 